Radosław Kucharczyk

Uniwersytet Warszawski, Instytut Romanistyki https://orcid.org/0000-0002-1861-1358 r.kucharczyk@uw.edu.pl

Krystyna Szymankiewicz Uniwersytet Warszawski, Instytut Romanistyki https://orcid.org/0000-0002-8598-3418 k.szymankiewicz@uw.edu.pl

\title{
ŚWIADOMOŚĆ WŁASNEGO PROCESU UCZENIA SIĘ JĘZYKÓW OBCYCH PRZYCZYNKIEM DO INNOWACYJNYCH DZIAŁAŃ DYDAKTYCZNYCH. W STRONĘ DYDAKTYKI WIELOJĘZYCZNOŚCI W POCZĄTKOWYM KSZTAŁCENIU NAUCZYCIELI
}

\begin{abstract}
Self-awareness of foreign language learning process as a precondition for innovative teaching. Towards multilingual didactics in the initial teachers' training

The aim of this article is to reflect on the initial training of teachers in line with the assumptions of multilingual didactics. A definition of plurilingual competence is given at the beginning of this article. We then discuss briefly about the main assumptions of plurilingual teaching. The next part of the article deals with the philosophy of educating future foreign language teachers in philological studies, which should be largely based on reflection. The article concludes with the analysis of data obtained from students participating in teacher education classes. The aim of the study was to diagnose whether the self-awareness of potential subjects, as given to them by the multilingual competence, could contribute to innovative teaching.
\end{abstract}

Keywords: multilingual didactics, initial foreign language teacher education, self-awareness, innovation 
Słowa kluczowe: dydaktyka wielojęzyczności, wstępne kształcenie nauczycieli języka obcego, samoświadomość, innowacja

\section{Wstęp}

Innowacyjność w edukacji jest pojęciem niezwykle pojemnym: zazwyczaj łączona jest z nowatorskimi rozwiązaniami służącymi optymalizacji kształcenia, z postawą twórczą, z przełamywaniem utartych schematów myślenia czy z interdyscyplinarnością (Majewska, 2016). W ramach przygotowania przyszłych nauczycieli języków obcych do podejmowania innowacyjnych działań dydaktycznych warto zwrócić uwagę na możliwość wykorzystania w tym celu elementów dydaktyki wielojęzyczności. Promowane przez Radę Europy od ponad dziesięciu lat rozwijanie kompetencji różnojęzycznej u uczniów nadal stanowi wyzwanie dla nauczycieli języków obcych - wyzwanie, któremu mogą oni stawić czoła przez innowacyjne w kontekście dydaktyki języka obcego działania dydaktyczne. W naszym przekonaniu punktem wyjścia do przygotowania nauczycieli do innowacji w zakresie rozwijania kompetencji różnojęzycznej jest uzyskanie świadomości własnego procesu uczenia się języków obcych, przy założeniu, że przyszli nauczyciele uczyli się nie tylko języka, którego będą nauczać, ale także przynajmniej jednego innego języka obcego ${ }^{1}$. Innymi słowy, nauczyciel, który wykorzystywał zasoby własnego repertuaru językowego w nauce języka docelowego, będzie mógł - w sposób świadomy - przekazać tę umiejętność swoim uczniom. W niniejszym artykule określimy, na czym polegają możliwe działania innowacyjne w dydaktyce wielojęzyczności, oraz omówimy warunki, jakie powinno spełniać kształcenie początkowe nauczycieli, by mogło prowadzić do nauczania języka obcego uwzględniającego repertuar językowy uczących się. Początkowe czy wstępne kształcenie nauczycieli oznacza prowadzone w szkołach wyższych kształcenie umożliwiające studentom zdobycie uprawnień pedagogicznych do nauczania języka obcego. Przez pojęcie repertuaru językowego rozumiemy wszystkie języki, które jednostka zna lub z którymi miała kontakt, w tym również jej język ojczysty. Szczególną uwagę poświęcimy sprawie świadomości studentów związanej z własnym procesem uczenia się języków, odniesiemy się przy tym do kwestii przydatności techniki autonarracji w tym zakresie.

\footnotetext{
${ }^{1}$ Ze względu na obowiązek nauki przynajmniej dwóch języków obcych w dawnym gimnazjum i liceum, jest to warunek spełniany przez studentów - kandydatów do zawodu nauczyciela języka obcego. Co więcej, student studiów filologicznych I stopnia musi zdać egzamin na poziomie B2 z języka obcego, innego niż język kierunkowy.
} 
Świadomość własnego procesu uczenia się języków obcych przyczynkiem do...

\section{Dydaktyka wielojęzyczności jako innowacja w procesie kształcenia językowego}

\subsection{Podejście wielojęzyczne i kompetencja różnojęzyczna}

Europejski System Opisu Kształcenia Językowego (2001/2003) (od tej pory ESOKJ) znacząco wpłynął na współczesną myśl glottodydaktyczną, pojawił się bowiem nowy paradygmat kształcenia językowego. Mowa o tzw. podejściu różnojęzycznym ${ }^{2}$, które zakłada, że w czasie komunikacji egzolingwalnej użytkownicy języka aktywują te ze składowych własnego repertuaru językowego, które zagwarantują im skuteczność aktu komunikacji. Dlatego jednym z głównych celów współczesnego kształcenia językowego powinna być praca nad rozwijaniem kompetencji różnojęzycznej uczniów, której definicja stanowi swoistego rodzaju (re)ewolucję w myśli glottodydaktycznej. Według tej definicji ${ }^{3}$ odchodzi się od klasycznej dychotomii: język ojczysty/język obcy na rzecz jednej, całościowej kompetencji, obejmującej cały repertuar językowy jednostki, z którego uczestnicy aktu komunikacji korzystają w zależności od kontekstu wymuszonego przez daną sytuację komunikacyjną. Można więc przyjąć, że kompetencja różnojęzyczna jest kompetencją zintegrowaną (Lüdi, 2016: 43), ponieważ nie jest sumą poszczególnych języków, które jednostka zna, lecz nicią powiązań, które te języki tworzą między sobą i z których jednostka korzysta w zależności od potrzeb, co podkreśla jej silnie zindywidualizowany charakter. Z powyższych ustaleń wynika, że kompetencja różnojęzyczna jest kompetencją funkcjonalną (Kucharczyk, 2015: 109-110), a więc specyficzną odmianą kompetencji adaptacyjnej. Kompetencja adaptacyjna to nic innego, jak zdolność do kreatywnego wykorzystania wiedzy i umiejętności nabytych w szkole w sytuacjach życia codziennego, co wymaga od ucznia aktywowania jego zasobów kognitywnych, motywacyjnych oraz afektywnych (Sujecka-Zając, 2016: 30-31). Warto również zaznaczyć, że kompetencja różnojęzyczna jest kompetencją ewolucyjną, ponieważ zmienia się wraz z doświadczeniem życiowym jednostki,

2 „(...) rozmówcy mogą przechodzić z jednego języka czy dialektu na inny, skutecznie wykorzystując umiejętność wypowiadania się w jednym języku, a rozumienia w drugim. W innym przypadku ktoś może próbować zrozumieć znaczenie tekstu napisanego lub wypowiedzianego w «nieznanym» mu wcześniej języku, korzystając ze swojej znajomości innych języków, czyli rozpoznając w nieznanym tekście słowa ze wspólnego, międzynarodowego zasobu leksykalnego" (ESOKJ,2003: 16).

3 „Kompetencja różnojęzyczna (...) odnosi się do umiejętności posługiwania się każdym ze znanych języków w celach komunikacyjnych (...), gdy dana osoba wykazuje różne stopnie sprawności w porozumiewaniu się kilkoma językami (...). Nie oznacza to hierarchicznego współistnienia oddzielnych kompetencji, lecz raczej istnienie jednej, złożonej kompetencji, z której korzysta użytkownik" (ESOKJ,2003: 145). 
które jest wypadkową jego kariery zawodowej, kontaktów służbowych/prywatnych czy też odbytych podróży (Robert i Rosen, 2010: 57-58).

Biorąc pod uwagę powyższe rozważania, można założyć potrzebę wdrażania tzw. dydaktyki wielojęzyczności. Jej celem jest takie zaplanowanie działań dydaktycznych na lekcji języka obcego, które umożliwiłoby uczniowi naukę języka docelowego w oparciu o nabyte uprzednio doświadczenie w uczeniu się języków (w tym również w nauce języka ojczystego).

\subsection{Dydaktyka wielojęzyczności - próba definicji}

Tak jak zauważyliśmy powyżej, celem dydaktyki wielojęzyczności jest wykorzystanie zasobów repertuaru językowego uczniów w nauce kolejnego języka/kolejnych języków. Innymi słowy, działania nauczyciela ukierunkowane są na wykształcenie u uczniów umiejętności dokonania pozytywnego transferu międzyjęzykowego. Taka umiejętność w dużej mierze zależy od postawy refleksyjnej ucznia, która z kolei umożliwia mu stworzenie zestawu strategii opartych na składowych jego repertuaru językowego ${ }^{4}$. Ponieważ zasoby repertuaru językowego każdego ucznia, składające się na jego kompetencję różnojęzyczną, są silnie zindywidualizowane, każdy ze wspomnianych elementów będzie inaczej aktywowany przez każdego z uczniów. Nauczyciel nie musi więc (a nawet nie może) znać wszystkich języków dostępnych uczniom, aby pomóc im w stworzeniu strategii prowadzących docelowo do świadomego transferu międzyjęzykowego. Wystarczy, jeśli - opierając się na własnym doświadczeniu w uczeniu się języków - pokaże im, jak mogą tworzyć silnie zindywidualizowaną sieć połączeń pomiędzy językami, aby łatwiej uczyć się języka docelowego.

\subsubsection{Refleksyjność}

Refleksyjność nie jest pojęciem nowym w kontekście procesu uczenia się i nauczania języków obcych. Może być ona zdefiniowana jako zdolność jednostki do zastanawiania się, rozważania oraz analizowania nabytego uprzednio doświadczenia, podjętych działań, odczuwanych emocji oraz - wynikających z nich - reakcji (Kruk, 2014: 213-215). Refleksyjność jest także postrzegana jako metakompetencja, która obejmuje cztery wymiary (Vacher, 2015: 31):

\footnotetext{
${ }^{4}$ Bardziej szczegółowe informacje dotyczące założeń dydaktyki wielojęzyczności znajdują się m.in. w takich monografiach, jak: Kucharczyk R. 2018. Nauczanie języków obcych a dydaktyka wielojęzyczności (na przykładzie francuskiego jako drugiego języka obcego). Lublin: Werset; Didactique du plurilinguisme. Approches plurielles des langues et des cultures. Autour de Michel Candelier. 2014. (red. Ch. Troncy). Rennes: Presses Universitaires de Rennes.
} 
- wymiar instrumentalny: umiejętność zracjonalizowania procesu uczenia się;

- wymiar heurystyczny: zauważenie związków pomiędzy elementami poddanymi analizie, co wywołuje refleksję;

- wymiar problematyzacji: stawianie i rozwiązywanie problemów;

- wymiar zmiany: tworzenie nowych wyobrażeń o działaniu.

Postawa refleksyjna warunkuje więc rozwój umiejętności uczenia się (Zdybel, 2015: 60), jest także jednym z warunków procesu uczenia się opartego na transferze wiedzy i umiejętności (Dubuc, 2013: 28). Dydaktyka wielojęzyczności jest w dużej mierze oparta na postawie refleksyjnej uczniów, która umożliwia im dokonywanie świadomych porównań pomiędzy językami wchodzącymi w skład ich repertuaru językowego. Refleksja uczniów obejmuje tak języki, które uczniowie już znają (włącznie z językiem ojczystym), jak i języki, które właśnie odkrywają (Kucharczyk, 2016: 247-248). Może ona dotyczyć elementów stricte językowych (gramatyka, słownictwo, fonetyka etc.) oraz składowych szerokorozumianej kompetencji komunikacyjnej (np. zarządzanie przebiegiem interakcji, rytuały otwierania i zamykania interakcji, struktura gatunków dyskursywnych). Co więcej, rozwiązywanie zadań językowych powinno być również oparte na refleksji, przy czym refleksja ta obejmuje zarówno doświadczenie jednostki nabyte w czasie rozwiązywania analogicznych zadań w innych językach, jak i refleksję na temat sposobu rozwiązania danego zadania. Taka postawa pozwala uczniowi wypracować wachlarz strategii wynikających z jego doświadczenia w uczeniu się języków obcych oraz oparty na zasobach jego repertuaru językowego.

\subsubsection{Strategie}

Podobnie jak refleksyjność, strategie uczenia się nie są pojęciem nowym w kontekście glottodydaktycznym. Pojawiło się ono już w latach 70. XX wieku jako nieodłączny element kompetencji komunikacyjnej. Strategie uczenia się mogą być określone jako działania ucznia (świadome lub nieświadome), które pozwalają mu lepiej opanować język obcy przy relatywnie niskim nakładzie pracy i w relatywnie krótkim czasie. W literaturze glottodydaktycznej znaleźć można wiele typologii strategii uczenia się, które są najczęściej przytaczane w pracach poświęconych temu zagadnieniu ${ }^{5}$. Niemniej jednak dokładna analiza wspomnianych wyżej klasyfikacji pozwala zaobserwować, że brakuje strategii, które byłyby oparte na repertuarze językowym ucznia, a co za tym idzie - strategii, które pozwoliłyby mu uczyć się kolejnych języków przy wykorzystaniu składowych jego

\footnotetext{
${ }^{5}$ Mowa tu przede wszystkim o klasyfikacjach strategii zaproponowanych przez następujących badaczy: J. Rubin (1989), J. M. O’Malley i A. U. Chamot (1990), H. H. Stern (1992), R. Oxford (1990) (za Droździał-Szelest, 1997).
} 
kompetencji różnojęzycznej. Można by więc pokusić się o stworzenie takiego zestawu strategii, który byłby oparty na wiedzy i umiejętnościach, jakimi uczniowie dysponują w innych językach (w języku ojczystym i językach obcych), i który nawiązywałby do trzech obszarów warunkujących proces uczenia się: poznawczego, metapoznawczego oraz społeczno-afektywnego. Strategie oparte na zasobach repertuaru językowego byłyby w ścisłym związku z pozostałymi strategiami uczeniowymi, które uczeń zwyczajowo aktywuje w czasie nauki języka, niemniej jednak łączyłby je wspólny mianownik, jakim jest dokonywanie świadomych porównań międzyjęzykowych. Strategie poznawcze dotyczyłyby nauki podsystemów języka (przede wszystkim słownictwa i gramatyki) oraz rozwijania sprawności językowych. Strategie metapoznawcze objęłyby zaś działania ucznia dotyczące planowania, kontrolowania i oceniania nauki kolejnego języka obcego oraz rozwiązywania zadań językowych. Natomiast strategie społecznoafektywne łączyłyby się z emocjami towarzyszącymi nauce języka oraz z interakcją z innymi osobami. Poniższa tabela pokazuje przykładowe strategie związane z aktywowaniem kompetencji różnojęzycznej przez uczniów.

\section{Wielojęzyczne strategie poznawcze}

Ucząc się języka docelowego (słownictwa, gramatyki, fonetyki, etc.), dokonuję porównań z innymi językami, które znam.

W językach, które znam, dostrzegam słowa zapożyczone z innych języków.

W językach, które znam, dostrzegam słowa „międzynarodowe” (tzw. internacjonalizmy lub słowa transparentne).

Ucząc się gramatyki języka docelowego, staram się dostrzec w jej zakresie regularności w odwołaniu do gramatyki języków, które znam.

W nauce języka docelowego wykorzystuję umiejętności - związane z czytaniem, pisaniem, mówieniem i ze słuchaniem - nabyte w innych językach.

Pamiętam, że różne typy tekstów w różnych językach mają ze sobą wiele punktów wspólnych.

Wielojęzyczne strategie metapoznawcze

Staram się określić, w jakim celu uczę się kolejnego języka.

Odwołując się do nabytego wcześniej doświadczenia w uczeniu się języków, staram się określić swoje słabe i mocne strony.

Przed przystąpieniem do rozwiązywania zadań w języku obcym zastanawiam się, w jaki sposób rozwiązałem podobne zadania w innych językach, które znam.

Staram się na bieżąco monitorować, w jakim stopniu znajomość języków jest mi przydatna w nauce kolejnego języka.

\begin{tabular}{l} 
Wielojęzyczne strategie społeczno-afektywne \\
$\begin{array}{l}\text { Wiem, że nauka języka jest procesem długotrwałym i wymagającym wysiłku, dlatego nie będę się zra- } \\
\text { żać podczas nauki kolejnego języka. }\end{array}$ \\
\hline $\begin{array}{l}\text { Komunikując się w kolejnym języku, którego się uczę, proszę rozmówcę o wsparcie i - jeśli to możliwie } \\
\text { - o używanie zwrotów/słów transparentnych. }\end{array}$
\end{tabular}

Tabela 1: Strategie wielojęzyczne. Źródło: Kucharczyk, 2018: 119-120. 


\subsubsection{Transfer}

Transfer, który stanowi główny trzon dydaktyki wielojęzyczności, jest wypadkową postawy refleksyjnej uczniów oraz aktywowanych przez nich strategii opartych na zasobach ich repertuaru językowego. Rola transferu w konstruowaniu przez uczniów wiedzy i umiejętności jest dwojaka (Arenilla et al., 2007: 315-316). Z jednej strony umożliwia on uczącym się wykorzystanie nabytej wiedzy i umiejętności w innych zakresach, z drugiej zaś pozwala im na ich pogłębienie i poszerzenie, ponieważ każda struktura poznawcza składa się z zasobów wiedzy i umiejętności, które jednostka integruje od pierwszych godzin swojego życia (Samson, 2011,on-line). Dlatego warto zachęcać nauczycieli do wyposażania uczniów w narzędzia, które pozwolą im na dokonanie transferu. Poniższa tabela przedstawia poszczególne etapy działań, o których mowa powyżej i które mogą być przydatne na lekcji języka obcego.

\begin{tabular}{|c|c|c|c|}
\hline Lp. & Etap & Cel & Zadanie nauczyciela \\
\hline 1. & $\begin{array}{l}\text { Uświadomienie sobie } \\
\text { nabytych uprzednio } \\
\text { wiedzy i umiejętności }\end{array}$ & $\begin{array}{l}\text { Stworzenie ram referencyjnych } \\
\text { w celu odkodowania nowych } \\
\text { informacji }\end{array}$ & $\begin{array}{l}\text { Postawienie uczniom serii py- } \\
\text { tań, które pozwolą im reakty- } \\
\text { wować nabytą uprzednio wie- } \\
\text { dzę i umiejętności, koniecznych } \\
\text { do rozwiązania nowego pro- } \\
\text { blemu poznawczego }\end{array}$ \\
\hline 2. & Kategoryzacja uczenia się & $\begin{array}{l}\text { Wypracowanie sieci pojęć, do } \\
\text { których można odnieść się w } \\
\text { czasie dokonywania transferu }\end{array}$ & $\begin{array}{l}\text { Pokazanie uczniom przykłado- } \\
\text { wych technik, które służą do } \\
\text { tworzenia sieci pojęciowych } \\
\text { (np. mapy myśli) }\end{array}$ \\
\hline 3. & Celowość uczenia się & $\begin{array}{l}\text { Zmotywowanie uczniów do } \\
\text { nauki }\end{array}$ & $\begin{array}{l}\text { Przedstawienie sytuacji/proble- } \\
\text { mów, które uczniowie znają }\end{array}$ \\
\hline 4. & $\begin{array}{l}\text { Transfer wiedzy } \\
\text { i umiejętności }\end{array}$ & Ułatwienie nauki & $\begin{array}{l}\text { Zaproponowanie takich sytuacj } \\
\text { dydaktycznych, które umożli- } \\
\text { wiają uczniom dokonanie trans- } \\
\text { feru (transfer eksplicytny } \rightarrow \\
\text { transfer implicytny) }\end{array}$ \\
\hline
\end{tabular}

Tabela 2: Etapy transferu. Źródło: Samson, 2011, on-line.

W kontekście dydaktyki wielojęzyczności, umiejętność dokonania transferu międzyjęzykowego jest wypadkową postawy refleksyjnej uczniów oraz stosowanych przez nich strategii w obrębie nie tylko podsystemów języka oraz komunikacji, ale także umiejętności uczenia się (Kucharczyk, 2016: 249-250). Warto więc zachęcać ucznia do świadomego korzystania z zasobów własnego repertuaru językowego w celu transferowania wiedzy i umiejętności, które nabył w zakresie np. słownictwa, gramatyki, fonetyki w różnych językach (w tym także w języku ojczystym). Podobnie rzecz ma się z komunikacją w języku docelowym, 
którą skutecznie zarządza przez odwołanie się do modeli komunikacyjnych znanych mu z innych języków. Transfer może dotyczyć także sposobów uczenia się języków: strategie uczenia się przetestowane i uznane za skuteczne w innych językach mogą być transferowalne w czasie nauki kolejnych języków.

Podsumowując, działania dydaktyczne wpisujące się w założenia dydaktyki wielojęzyczności można uznać za innowację pedagogiczną, pod warunkiem właściwego przygotowania nauczycieli. Działania te można uznać za innowacyjne, ponieważ wywołały one istotną zmianę w procesie kształcenia językowego, mającą na celu jego ulepszenie przez korzystanie z zasobów repertuaru językowego uczniów. Jest to innowacja o charakterze wycinkowym, ponieważ dotyczy tylko jednego z elementów systemu edukacyjnego, czyli stosowanych metod nauczania (Kupisiewicz i Kupisiewicz, 2009: 67).

\section{Dydaktyka wielojęzyczności jako innowacja w procesie początkowego kształcenia nauczycieli}

Początkowe kształcenie nauczycieli języków obcych w ramach studiów filologicznych łączy się zazwyczaj ze skupieniem się na nauczaniu jednego języka obcego i przyjęciem wzorca normatywnego, odnoszącego się do modelu native-speakera (Montagne-Macaire, 2008: 14). W związku z tym można przyjąć, że postulowane $w$ niniejszym artykule przygotowanie studentów kursu metodycznego do innowacyjnego praktykowania dydaktyki wielojęzyczności samo w sobie stanowi innowację na poziomie edukacji nauczycielskiej. W jaki sposób tę innowację wprowadzić? Jak przygotować przyszłych nauczycieli do podjęcia wysiłku implementowania dydaktyki wielojęzyczności na lekcjach nauczanego przez nich języka? Ponieważ jesteśmy zdania - co zostało podkreślone wcześniej - że kluczem do działań innowacyjnych, związanych z dydaktyką wielojęzyczności, jest uzyskanie przez uczących się samoświadomości własnego procesu uczenia się $w$ drodze rozwoju refleksyjności, strategii i transferu, tę samą zasadę odniesiemy do kształcenia nauczycieli.

Kształtowanie postawy refleksyjnej ma ugruntowaną pozycję w dziedzinie edukacji nauczycielskiej. Świadczy o tym popularny od lat 90 . XX wieku model refleksyjnej praktyki inspirowany koncepcją D. Schöna (1983), a akcentujący rolę refleksji nad działaniem, łączenia teorii z praktyką dla rozwoju zawodowego nauczycieli (Farrell, 2007). Jednak, mając na uwadze przygotowanie przyszłych nauczycieli do stosowania zasad dydaktyki wielojęzyczności w nauczaniu języka obcego, należałoby poszerzyć pole refleksji o aspekty związane z samopoznaniem w zakresie metakognitywnym w kontekście nauki języków. Oznacza to, po pienwsze, iż studenci - kandydaci do zawodu nauczyciela, powinni mieć okazję, by uświadomić sobie własne teorie osobiste dotyczące uczenia się/nauczania 
Świadomość własnego procesu uczenia się języków obcych przyczynkiem do...

języków (Farrell, 2007: 7; Michońska-Stadnik, 2013: 29; Szymankiewicz, 2013: 267). Jest to ważne, gdyż teorie osobiste - czyli osobista wiedza praktyczna, zbudowana na bazie przekonań, wartości i własnego doświadczenia - decydują o sposobie działania nauczycieli, nawet jeśli okazuje się ono sprzeczne z deklaratywnie przyswojoną wiedzą teoretyczną (Polak, 1999; Crahay et al., 2010). $Z$ tego względu wskazane jest poddawanie teorii osobistych krytycznej refleksji i ich modyfikowanie w oparciu o wnioski płynące z konfrontacji wiedzy teoretycznej z praktyką nauczania (Kwiatkowska, 2008: 123). Jedno z przeprowadzonych przez nas badań pokazało, że teorie osobiste studentek - przyszłych nauczycielek języka francuskiego, odzwierciedlają typowe dla uczniów polskiej szkoły doświadczenie uczenia się dwóch lub trzech języków obcych, jednak każdego w sposób oderwany i niezależny od pozostałych, a przy tym nacechowany dążeniem do doskonałej ich znajomości (Kucharczyk i Szymankiewicz, 2016). W tym kształcie, teorie osobiste osób badanych z pewnością nie sprzyjałyby pracy nad wielojęzycznością uczniów w szkole.

Wydaje się, że dobrym sposobem na przekształcanie teorii osobistych na temat uczenia się języków i poznawania kultur jest odkrywanie przez przyszłych nauczycieli własnej różnorodności językowej i kulturowej, dającej się stwierdzić nawet w przypadku życia w kraju monolingwalnym. Pomocna może być tu również refleksja nad własną biografią oraz tożsamością językową i kulturową ${ }^{6}$. Działania zmierzające $w$ tym kierunku pozwalają odkryć bogactwo, złożoność i wartość własnego repertuaru językowego oraz zrozumieć sens rozwijania kompetencji różnojęzycznej i różnokulturowej jako aspektu rozwoju osobistego.

Po drugie, refleksją należałoby objąć wyobrażenia na temat roli i funkcji współczesnego nauczyciela języka obcego (Szymankiewicz, 2017: 43). Zauważmy, że przyszły nauczyciel, akceptując ideę dydaktyki wielojęzyczności, godzi się de facto na przyjęcie roli współuczącego się wraz ze swoimi uczniami, co kłóci się z powszechną tendencją do przypisywania mu roli eksperta i modelu językowego (Gruca, 2010: 21).

Po trzecie, istotne jest praktykowanie refleksji nad własną umiejętnością uczenia się, a zwłaszcza stosowanymi strategiami uczenia się i ich ewolucją w trakcie uczenia się kolejnych języków. Studenci mają przecież za sobą wieloletnie doświadczenie w nauce przynajmniej dwóch języków obcych - doświadczenie, które warto poddać analizie w celu zauważenia możliwości dokonywania transferu określonych strategii (np. czytania tekstu, uczenia się gramatyki), a także uświadomienia sobie własnych preferencji w zakresie stylów

\footnotetext{
${ }^{6} \mathrm{~W}$ tym celu można posłużyć się np. zadaniami zebranymi w materiałach do kształcenia nauczycieli, Bernaus M.et al.La dimension plurilingue et pluriculturelle dans la formation des enseignants de langues czy też w Europejskim portfolio językowym.
} 
uczenia się i odpowiadających im strategii. W celu pogłębienia metapoznania przyszłych nauczycieli języków obcych przydatna wydaje się technika autonarracji, o której zaletach opowiemy nieco dalej, przy okazji przedstawienia badań własnych.

$\mathrm{Na}$ koniec warto wspomnieć o potrzebie prowadzenia refleksji metajęzykowej. Mimo że studia filologiczne z zasady rozwijają ten typ refleksji i wrażliwości, to jednak zbyt często, jak zostało to już podkreślone, refleksja metajęzykowa odnosi się jedynie do wiodącego na danym kierunku języka obcego. Wskazane wydaje się zatem poszerzenie wiedzy o różnych systemach językowych, analizowanie podobieństw i różnic między językami studentów (np. polski - angielski - francuski - hiszpański - włoski), co powinno prowadzić tak do poszukiwania możliwości pozytywnego transferu, jak i do wzrostu świadomości pułapek transferu negatywnego.

Podkreślić należy, że za każdym razem podstawą do refleksji musi być WIEDZA - wiedza na temat teorii akwizycji językowej, zasad dydaktyki wielojęzyczności, koncepcji kompetencji różnojęzycznej i różnokulturowej, strategii uczenia się języków, systemów językowych różnych języków, podobieństw i różnic między językami, których naucza się w polskiej szkole. Chodzi przy tym o to, by $w$ trakcie kształcenia wiedza ta nie była przedstawiona jako bezdyskusyjny pewnik, ale została użyta do przemyślenia przez studentów własnych koncepcji nauczania i poddana subiektywizacji oraz - jeśli to tylko możliwe - skonfrontowana z praktyką szkolnego nauczania (Sajdak, 2010: 130).

\section{Badanie własne}

\subsection{Aspekty metodologiczne (cel badania, wybór metody i technik, dobór próby badawczej)}

W ramach kształcenia wstępnego nauczycieli języka francuskiego w Instytucie Romanistyki UW od kilku lat przygotowujemy studentów do stosowania dydaktyki wielojęzyczności i jednocześnie prowadzimy badania nad różnymi aspektami gotowości kandydatów na nauczycieli do podjęcia tego wyzwania (Kucharczyk i Szymankiewicz, 2015; Kucharczyk i Szymankiewicz, 2016; Szymankiewicz i Kucharczyk, 2016). W dalszej części niniejszego artykułu przedstawimy badanie własne, stanowiące trzeci etap szerszego badania poświęconego temu zagadnieniu. Kolejne etapy badania zostały przedstawione w poniższej tabeli.

Badanie zostało przeprowadzone na próbie 20 studentek Instytutu Romanistyki UW ( $\mathrm{N}=20)$, które realizowały zajęcia bloku nauczycielskiego w roku akademickim 2014/2015. Wśród badanych przeważały osoby studiujące na II roku studiów I stopnia, kilka osób studiowało na I roku studiów magisterskich. 
Świadomość własnego procesu uczenia się języków obcych przyczynkiem do...

\begin{tabular}{|c|c|c|c|}
\hline Lp. & Etap badania & Cel & Użyte narzędzia \\
\hline 1. & Schemat heurystyczny „Wielojęzyczność” & $\begin{array}{l}\text { Poznanie reprezentacji spo- } \\
\text { łecznych studentów dotyczą- } \\
\text { cych zjawiska wielojęzyczności }\end{array}$ & \begin{tabular}{|l|} 
Karton ze zdjęciem \\
dziecka wieloję- \\
zycznego
\end{tabular} \\
\hline 2. & $\begin{array}{l}\text { Ankieta „Wielojęzyczność na lekcji języka } \\
\text { obcego"8 }\end{array}$ & $\begin{array}{l}\text { Diagnoza stopnia wiedzy do- } \\
\text { tyczącej wielojęzyczności oraz } \\
\text { kompetencji różnojęzycznej w } \\
\text { kontekście kształcenia języko- } \\
\text { wego }\end{array}$ & $\begin{array}{l}\text { Kwestionariusz an- } \\
\text { kiety }\end{array}$ \\
\hline 3. & $\begin{array}{l}\text { Wypracowanie nt. „Zastanów się, w jaki spo- } \\
\text { sób uczyłeś/uczyłaś się języków obcych, } \\
\text { które znasz lub którymi się posługujesz. Czy } \\
\text { w nauce wykorzystywałeś/wykorzystywałaś } \\
\text { znajomość innych języków? Napisz krótki } \\
\text { tekst (25-300 słów) o swoich doświadcze- } \\
\text { niach jako osobyuczącej się. W swojej wypo- } \\
\text { wiedzi odwołaj się m.in. do następujących } \\
\text { elementów: słuchanie i czytanie ze zrozu- } \\
\text { mieniem, mówienie, pisanie, nauka słownic- } \\
\text { twa, nauka gramatyki” }\end{array}$ & $\begin{array}{l}\text { Poznanie doświadczenia przy- } \\
\text { szłych nauczycieli języka fran- } \\
\text { cuskiego dotyczącego uczenia } \\
\text { się języków obcych }\end{array}$ & $\begin{array}{l}\text { Wydruk z tema- } \\
\text { tem wypracowa- } \\
\text { nia }\end{array}$ \\
\hline
\end{tabular}

Tabela 3: Etapy procedury badawczej. Źródło: opracowanie własne.

Analiza przygotowanych przez studentki map myśli (pierwszy etap badania) pokazała, że ich wizja dotycząca pojęcia wielojęzyczność jest dość stereotypowa. Studentki są przekonane, że osoba wielojęzyczna powinna znać poszczególne języki w stopniu doskonałym, a warunkiem stania się osobą wielojęzyczną jest codzienny i bezpośredni kontakt z językiem w środowisku rodzinnym lub szkolnym. Uważają również, że wielojęzyczność jest zjawiskiem rzadkim w Polsce i nie utożsamiają jej ze szkolną nauką języków.

Z kolei w odpowiedziach na pytania zawarte w kwestionariuszu ankiety (drugi etap badania)można znaleźć elementy, które mogą potencjalnie blokować rozwijanie kompetencji różnojęzycznej u przyszłych uczniów badanych studentek, np. dychotomiczne traktowanie języków, stereotypowe postrzeganie trudności w uczeniu się języków czy też odwoływanie się do modelu rodzimego użytkownika języka jako modelu referencyjnego w procesie kształcenia językowego, który może ujemnie wpłynąć na motywację do nauki, zwłaszcza na jej początkowym etapie.

\footnotetext{
7 Badanie zostało opisane w: Kucharczyk R., Szymankiewicz K. 2015. „Kompetencja różnojęzyczna w początkowym kształceniu nauczycieli”. Neofilolog, 45/1: 73-86.

${ }^{8}$ Badanie zostało opisane w: Kucharczyk R., Szymankiewicz K. 2016. „Teorie osobiste dotyczące rozwijania kompetencji różnojęzycznej na lekcjach języka obcego - przypadek przyszłych nauczycieli języka francuskiego". Języki Obce w Szkole, 4: 64-70.
} 
Trzecim etapem badania było - jak już wspomniano - zbadanie doświadczenia, jakie studentki bloku metodycznego posiadają w zakresie uczenia się języków obcych. W badaniu zastosowano metodę autonarracji. Autonarracja zaliczana jest do metod jakościowych badań typu indukcyjnego i eksplora cyjnego, a jej celem jest uchwycenie subiektywnej perspektywy badanych w odniesieniu do wybranego wątku (Smuk, 2016: 142-143). W opisywanym przez nas przypadku chodziło o zdiagnozowanie podejścia studentek do uczenia się języków oraz przejawianej świadomości stosowanych strategii uczenia się w kontekście wykorzystywania znajomości innych języków. Jednocześnie mieliśmy na uwadze wartość autonarracji dla samych osób badanych. Wiadomo bowiem, że związane z pisaniem autonarracji dokonywanie introspekcji pozwala spojrzeć na własne doświadczenie z dystansu, służącego jego zrozumieniu, co prowadzi do lepszego samopoznania i wzbogacenia samowiedzy (Morisse, 2014: 20; Smuk, 2016: 142). W ten sposób element badania stanowił zarazem narzędzie kształcenia, umożliwiające zyskanie przez osoby badane świadomości własnej umiejętności uczenia się wielojęzycznego. Naszym zdaniem świadomość tę należy uznać za punkt wyjścia do rozwijania strategii uczenia się i nauczania wielojęzycznego.

\subsection{Analiza autonarracji}

Wśród wypowiedzi badanych studentek można znaleźć siedemnaście autonarracji, których autorki wskazują na korzystanie z zasobów własnego repertuaru językowego w czasie uczenia się kolejnych języków obcych. Trzy osoby ${ }^{9}$ nie odniosły się w swoich wypowiedziach do tej kwestii, mimo że była ona zawarta w temacie wypracowania.

Trzeba też podkreślić, że siedem studentek ${ }^{10}$ wspomina o korzystaniu z zasobów własnego repertuaru językowego w sposób ogólnikowy - nie przedstawia żadnych wyraźnych strategii, np.:

Kiedy opanowałam język obcy i rozpoczęłam naukę drugiego języka obcego, to było mi o wiele łatwiej. Wiedziałam dokładnie na co mam zwracać uwagę, aby dobrze poznać język. (S7)

Zauważyłam, że nauka języka włoskiego jako innego języka romańskiego była łatwiejsza dzięki znajomości francuskiego. (S11)

W autonarracjach dziesięciu osób badanych ${ }^{11}$ można natomiast odnaleźć strategie wykorzystywania znajomości języków w akwizycji językowej. I tak,

\footnotetext{
${ }^{9} \mathrm{~S} 1, \mathrm{~S} 8, \mathrm{~S} 9$.

${ }^{10}$ S2, S4, S5, S7, S11, S14, S15.

${ }^{11}$ S3, S6, S10, S12, S13, S16, S17, S18, S19, S20.
} 
Świadomość własnego procesu uczenia się języków obcych przyczynkiem do...

w nauce słownictwa najczęściej wymieniana jest strategia poszukiwania analogii pomiędzy słowami w różnych językach w celu ich zapamiętania ${ }^{12}$ :

Np. w słownictwie często wiq̨załam nowq definicję lub słowo z wcześniej poznanym jego odpowiednikiem w innym języku obcym. (S3)

Słownictwo to była analogia z angielskiego na francuski i odwrotnie. (S16)

W jednym przypadku pojawia się stosowana w dzieciństwie strategia tłumaczenia nieznanych słów na język ojczysty:

W nauce języka angielskiego (od 7-go roku życia, I klasy szkoły podstawowej) na pewno wykorzystywałam znajomość języka polskiego, żeby przetłumaczyć słówka i się ich nauczyć. (S13)

Podobnie jak w podejściu do słownictwa, w nauce gramatyki podstawowa strategia polega na porównywaniu struktur językowych w różnych językach ${ }^{13}$ :

W nauce hiszpańskiego (od 16-go roku życia, pozalekcyjne) bardzo pomógł mi język francuski. Bardzo podobne koniugacje, czasy, tryby, słownictwo.(S13)

Jedna osoba zaleca ostrożność ze względu na występowanie fałszywych podobieństw:

Jeżeli chodzi o naukę gramatyki trzeba być dużo bardziej elastycznym i nie zawsze sugerować się innym językiem, ponieważ może on różnić się w znacznym stopniu od nowo poznanego języka, co właśnie zauważyłam porównując język włoski z językiem francuskim. (S12)

W przypadku rozwijania sprawności rozumienia, sześć studentek ${ }^{14}$ wskazuje na możliwość domyślania się znaczenia słów przez analogię do znanych języków, zwłaszcza z tej samej rodziny językowej:

W szczególności pomagajq mi podobieństwa, które w sposób intuicyjny służq do rozpoznawania słownictwa. (S12)

Od samego poczq̨tku potrafiłam zrozumieć różne teksty pisane [po hiszpańsku], gdyż domyślałam się znaczenia słówek poprzez analogię z językiem francuskim i czasami też angielskim. (S19)

\footnotetext{
12 S3, S13, S16, S17, S18, S19.

13 S3, S13, S16, S18, S19, S20.

14 S6, S10, S12, S13, S19, S20.
} 
Jednocześnie jedna osoba podkreśla istnienie różnic w wymowie między językami i wynikającą stąd konieczność osłuchiwania się z nowo poznawanym językiem (S12).

W zakresie wypowiedzi pisemnej wymieniono strategię transferu dyskursywnego schematu tekstu:

Jeśli chodzi o pisanie, to miałam w głowie już gotowy schemat: zmieniałam tylko język (ale pamiętałam jednocześnie, że wszystko trzeba sprawdzić, bo to co może wydawać się pewne, okazuje się złe). (S3)

Wypowiedź ustna dla jednej z badanych studentek łączy się z użyciem komunikacyjnych strategii kompensacyjnych:

Intuicyjnie "wymyślałam" słownictwo na bieżqco (np. wypowiadajqc francuskie słowa z hiszpańskim akcentem) i zazwyczaj niewiele się myliłam. (S13)

Dwie studentki ${ }^{15}$ zauważają potrzebę świadomej pracy nad wymową języka docelowego.

Na podstawie powyższych obserwacji można stwierdzić, że u połowy osób badanych korzystanie z własnego repertuaru językowego w nauce języków albo nie miało miejsca, albo zachodziło w sposób ograniczony i intuicyjny. Pozostała połowa badanych studentek była w stanie uświadomić sobie i przedstawić, choć czasem w dość ogólny sposób, strategie wielojęzyczne odnoszące się przynajmniej do jednego z obszarów uczenia się języka obcego (słuchanie i czytanie ze zrozumieniem, mówienie, pisanie, nauka słownictwa, nauka gramatyki). Taki stan rzeczy wskazuje na potrzebę rozwijania umiejętności uczenia się przyszłych nauczycielek języka francuskiego pod kątem strategii opartych na podejściach wielorakich.

Analiza autonarracji pokazała też, że świadome poszukiwanie analogii między poznawanymi językami pojawia się u osób badanych na etapie liceum, a najczęściej praktykowane jest podczas studiów w ramach nauki kolejnego języka romańskiego (włoski, hiszpański), np.:

[Ucząc się francuskiego] Nie wykorzystywałam nigdy znajomości innych języków tj. angielskiego, bo byłam mała żeby uczyć się stosujqqc analogię. W obecnym momencie robię to świadomie przy nauce języka włoskiego. (S2)

Wydaje się zatem, że w kształceniu początkowym nauczycieli na filologii romańskiej warto wykorzystać okoliczności sprzyjające rozwojowi świadomości

${ }^{15}$ S17, S19. 
metajęzykowej i kompetencji różnojęzycznej, które wiążą się z często wybieraną przez studentów nauką drugiego języka romańskiego.

Interesująca jest także świadomość własnych, „klasycznych” strategii uczenia się języków, przejawiana przez osoby badane w tekstach autonarracji. Dziesięć studentek ${ }^{16}$ uwzględniło ten aspekt w swojej opowieści o uczeniu się języków, wymieniając takie strategie, jak: czytanie książek i prasy, oglądanie telewizji, filmów, słuchanie radia, piosenek oraz tradycyjne robienie ćwiczeń gramatycznych i leksykalnych czy redagowanie wypowiedzi pisemnych, np.:

Była to nauka języka angielskiego, którego bardzo dużo nauczyłam się słuchajqc angielskojęzyczne piosenki, mnóstwo słówek zostawało mi w pamięci. (...) Wnauce francuskiego pomogło mi bardzo oglqdanie telewizji czy czytanie gazet. (S11)

Jeżeli uczę się dla przyjemności: słucham radia w języku francuskim, oglq̨dam bajki, filmy, pierwszy raz zawsze z napisami, dopiero za drugim razem wyłqczam. Te metody pozwalajq mi na powtórzenie słownictwa, ponieważ często pojawiajq się tam słówka, których kiedyś się uczyłam, ale używałam ich na co dzień. Uczę się w ten sposób również rozumienia ze słuchu. (S17)

Trzy osoby ${ }^{17}$ podkreślają skuteczność uczenia się języka w naturalnym kontekście komunikacyjnym, np.:

Podczas mojej nauki języków w szkole (w szkole językowej) w domu nacisk kładziony był głównie na gramatykę i naukę słownictwa, potem na mówienie, pisanie, słuchanie i czytanie ze zrozumieniem. Najwięcej jednak dała mi roczna wymiana na którq wyjechałam po I klasie liceum (Amiens 2011/2012). Mieszkajqc we Francji nauczyłam się języka dość szybko, głównie słuchajqc i mówiq̨c. Oczywiście po powrocie do Polski musiałam nadrobić gramatykę. (S4)

Opisywanie własnych strategii uczenia się prowadzi nieraz do metaświadomości obejmującej własne mocne i słabe strony wynikające z uwarunkowań osobowościowych, jak w przypadku osoby S15, świadomej swojej nieśmiałości:

Największq trudność sprawiały mi zawsze wystąienia publiczne, niezależnie od języka w którym się wypowiadałam. Najłatwiej było mi słuchać i czytać ze zrozumieniem. Praca indywidualna sprawiała mi najwięcej radości. (S15)

Refleksja badanych studentek na temat własnych strategii uczenia się języków, powodów ich wyboru oraz ocena ich skuteczności pozwalają spojrzeć

\footnotetext{
${ }^{16}$ S1, S4, S6, S7, S11, S14, S15, S17, S18, S20.

17 S4, S7, S20.
} 
na naukę języków w sposób globalny, co może prowadzić do uświadomienia sobie możliwości transferu strategii przy uczeniu się kolejnych języków, jak to w sposób dość ogólny czyni S18:

Analizujqc same techniki nauczania zawsze były takie same mimo znajomości nowych sposobów zapamiętywania zawsze pozostawałam przy starych sprawdzonych metodach. (S18)

\section{Wnioski z badania i podsumowanie}

Przeprowadzona analiza autonarracji przyszłych nauczycielek języka francuskiego na temat własnej nauki języków obcych pozwoliła stwierdzić, że pisemna autorefleksja stanowi potencjalne narzędzie rozwijania samoświadomości uczenia się języków. Dzięki autonarracji możliwe staje się globalne spojrzenie na własną ścieżkę rozwoju repertuaru językowego, zauważenie posiadanych preferencji w zakresie strategii uczenia się, dostrzeżenie analogii bądź różnic między procesami uczenia się określonych języków. Trzeba jednak podkreślić, że w przypadku części osób badanych, potencjał autonarracji nie został w pełni wykorzystany - świadczą o tym ogólnikowe stwierdzenia dotyczące uczenia się języków bądź nawet brak ustosunkowania się do kwestii możliwości korzystania z własnego repertuaru językowego podczas nauki. Stosowanie autonarracji w kształceniu nauczycieli w badanym przez nas kontekście należy z pewnością poddać treningowi w celu pogłębienia umiejętności autorefleksji.

Przechodząc do szerszego podsumowania przedstawionych w artykule rozważań teoretycznych i empirycznych, pragniemy zaznaczyć, że idea kształcenia początkowego nauczycieli języków obcych, z założeniem przygotowania ich do praktykowania dydaktyki wielojęzyczności, wymaga jednoczesnego rozwijania sprzężonych ze sobą wymiarów kompetencji zawodowej: wiedzy, umiejętności praktycznych, samoświadomości i samoregulacji w zakresie uwarunkowań osobowościowych oraz umiejętności uczenia się. Z tego względu warto rozważyć rozwijanie u przyszłych nauczycieli specyficznych obszarów kompetencji, których przykładowy zestaw przedstawia poniższa tabela.

Tak zarysowany wieloaspektowy i globalny zarazem sposób rozwijania samoświadomości studentów w zakresie własnego procesu uczenia się języków ma szanse przełożyć się na podejmowanie przez przyszłych nauczycieli działań innowacyjnych z zakresu dydaktyki wielojęzyczności, gdyż pozwala, poprzez refleksję, dostrzec i zrozumieć sens rozwijania kompetencji różnojęzycznej u uczniów na podstawie własnego doświadczenia w uczeniu się, wspartego wiedzą, doskonalonymi umiejętnościami praktycznymi, umiejętnością uczenia się oraz zrozumieniem roli uwarunkowań osobowościowych. 
Świadomość własnego procesu uczenia się języków obcych przyczynkiem do...

\begin{tabular}{|c|c|}
\hline $\begin{array}{l}\text { Obszar w struk- } \\
\text { turze kompeten- } \\
\text { cji zawodowej }\end{array}$ & Elementy kompetencji potrzebne do praktykowania dydaktyki wielojęzyczności \\
\hline Wiedza & $\begin{array}{l}\text { - znajomość teorii akwizycji językowej, również tej dwujęzycznej i wielojęzycznej } \\
\text { - znajomość pojęć: interjęzyk, transfer intralingwalny i międzyjęzykowy, pozytywny } \\
\text { i negatywny, strategie uczenia się (typologie), repertuar językowy, kompetencja } \\
\text { różnojęzyczna i różnokulturowa } \\
\text { - wiedza o języku jako systemie, jego podsystemach } \\
\text { - wiedza o różnicach i podobieństwach między językami, których uczą się polscy } \\
\text { uczniowie (np. między angielskim a francuskim) } \\
\text { - znajomość zasad podejść wielorakich w ramach dydaktyki wielojęzyczności } \\
\text { •... }\end{array}$ \\
\hline & $\begin{array}{l}\text { - odkrywanie wstępnych reprezentacji uczniów na temat języków i ich nauki } \\
\text { - opracowanie kontraktu dydaktycznego precyzującego cele i sposoby używania } \\
\text { różnych języków podczas lekcji danego języka obcego } \\
\text { - analiza i interpretacja błędów popełnianych przez uczniów w kontekście wpły- } \\
\text { wów międzyjęzykowych } \\
\text { - planowanie i stwarzanie sytuacji wyzwalających refleksję metajęzykową i meta- } \\
\text { poznawczą uczniów } \\
\text { - stosowanie podczas lekcji danego języka obcego elementów podejść wielora- } \\
\text { kich, np. interkomprehensji, dydaktyki zintegrowanej czy podejścia interkulturo- } \\
\text { wego } \\
\text { - praktyczna znajomość języków (np. nauczyciel języka francuskiego powinien znać } \\
\text { przynajmniej jeszcze język angielski oraz ewentualnie drugi język romański) }\end{array}$ \\
\hline $\begin{array}{l}\text { Uwarunkowania } \\
\text { osobowościowe }\end{array}$ & $\begin{array}{l}\text { - uświadomienie sobie własnej kompetencji różnojęzycznej i różnokulturowej } \\
\text { - uświadomienie sobie i ewentualna modyfikacja własnego nastawienia do rozwi- } \\
\text { jania kompetencji różnojęzycznej i różnokulturowej u siebie i u innych } \\
\text { • zaakceptowanie roli współuczącego się, towarzysza nauki, a nie modelu } \\
\text { - wykazywanie empatii poznawczej wobec uczniów w zakresie ich rytmu nauki, ich } \\
\text { biografii językowej, ich motywacji do nauki języków } \\
\text { - wzbudzanie motywacji uczniów do nauki różnych języków, nie tylko języka an- } \\
\text { gielskiego } \\
\text { - podejmowanie współpracy z nauczycielami innych języków } \\
\text { - rozwijanie postawy refleksyjnej wobec własnej praktyki } \\
\text { - nieustanne dążenie do samorozwoju, poszerzania wiedzy, doskonalenia umiejęt- } \\
\text { ności praktycznych } \\
\text { •... }\end{array}$ \\
\hline $\begin{array}{l}\text { Umiejętność } \\
\text { uczenia się }\end{array}$ & $\begin{array}{l}\text { - uświadomienie sobie stosowanych strategii uczenia się języków obcych } \\
\text { - rozwijanie różnorodnych strategii uczenia się, służących rozwijaniu kompetencji } \\
\text { różnojęzycznej (w zakresie nauki słownictwa, gramatyki, rozumienia ze słuchu, } \\
\text { czytania, mówienia i pisania) - patrz tabela 1. } \\
\text {-... }\end{array}$ \\
\hline
\end{tabular}

Tabela 4: Obszary kompetencji zawodowej nauczyciela. Źródło: Szymankiewicz, 2018 (w druku). 


\section{BIBLIOGRAFIA}

Arenilla, L. et al. 2007. Dictionnaire de pédagogie et de l'éducation. Paris: Bordas. Bernaus, M., Andrade, A. I., Kervran, M., Murkowska, A. i Trujillo Sáez, F. 2007. La dimension plurilingue et pluriculturelle dans la formation des enseignants de langues. Kit de formation. Graz/Strasbourg: Centre européen pour les langues vivantes/Editions du Conseil de l'Europe.

Crahay, M., Wanlin, Ph., Issaieva, E. i Laduron, I. 2010. „Fonctions, structuration et évolution des croyances (et connaissances) des enseignants". Révue française de pédagogie. Recherches en éducation, $\mathrm{n}^{\circ}$ 172: 85-129.

Didactique du plurilinguisme. Approches plurielles des langues et des cultures. Autour de Michel Candelier. 2014. (red. Ch. Troncy). Rennes: Presses Universitaires de Rennes.

Droździał-Szelest, K. 1997. Language learning strategies in the process of acquiring a foreign language. Poznań: Motivex.

Dubuc, M. 2013. Apprendre avec des outils pédagogiques " facilitateurs de pensée ». Gestion mentale et transfert des apprentissages. Lyon: Chronique Sociale.

Europejski System Opisu Kształcenia Językowego. 2003.Warszawa: Centralny Ośrodek Doskonalenia Nauczycieli.

Europejskie portfolio językowe. http://portfoliojezykowe.wordpress.com.

Farrell, T.S. 2007. Reflective language teaching: from research to practice. London:Bloomsbury Academic.

Gruca, I. 2010. „Le métier de professeur de langue étrangère”. (w:) Développer les compétences multiples chez l'apprenant et chez l'enseignant en classe de FLE. (red. K. Szymankiewicz i J. Zając). Warszawa: Instytut Romanistyki UW, s. 17-24.

Kruk, M. 2014. „Refleksja nad uczeniem się gramatyki na lekcjach języka angielskiego z wykorzystaniem zasobów Internetu i świata wirtualnego". (w:) Refleksja w uczeniu się i nauczaniu języków obcych. (red. M. Baran-Łucarz). Wrocław: Wydawnictwo Uniwersytetu Wrocławskiego, s. 213-226.

Kucharczyk, R. 2015. "L'anglais au service du français ? Utiliser le répertoire langagier des apprenants en classe de FLE". (w:) Enseignement/apprentissage du français face aux défis de demain. (red. M. Sowa). Lublin:Werset, s. 108-119.

Kucharczyk, R. 2016. „Développer la compétence plurilingue dans un pays monolingue. Quelles implications pour l'apprentissage/enseignement de la deuxième langue étrangère ? Le cas des élèves polonais". (w:) Actas del III Congreso Internacional Nebrija en Lingüística Aplicada a la Enseñanza de Lenguas. Nebrija: Nebrija Procedia, s.245-259. 
Kucharczyk, R. 2018. Nauczanie języków obcych a dydaktyka wielojęzyczności (na przykładzie francuskiego jako drugiego języka obcego). Lublin: Wydawnictwo Werset.

Kucharczyk, R. i Szymankiewicz, K. 2015. „Kompetencja różnojęzyczna w początkowym kształceniu nauczycieli". Neofilolog, 45/1: 73-86.

Kucharczyk, R. i Szymankiewicz, K. 2016. „Teorie osobiste dotyczące rozwijania kompetencji różnojęzycznej na lekcjach języka obcego - przypadek przyszłych nauczycieli języka francuskiego". Języki Obce w Szkole, 4: 64-70.

Kupisiewicz, Cz. i Kupisiewicz, M. 2009. Słownik pedagogiczny. Warszawa: Wydawnictwo Naukowe PWN.

Kwiatkowska, H. 2008. Pedeutologia. Warszawa: Wydawnictwa Akademickie i Profesjonalne.

Lüdi, G. 2016. „Du plurilinguisme comme tare au plurilinguisme comme atout. L'héritage de l'idéologie monolingue". (w:) L'éducation plurilingue. Contextes, représentations, pratiques. (red. G.Komur-Thilloy i U. PaprockaPiotrowska). Paris: Orizons, s.31-53.

Majewska, M. 2016. „Innowacyjność w pedagogice. Co to znaczy?”. (w:)Publikacja pokonferencyjna „Pokazać -Przekazać 2016”. http://www.kopernik.org.pl/projekty-specjalne/konferencja-pokazac-przekazac/.

Michońska-Stadnik, A. 2013. Teoretyczne i praktyczne podstawy weryfikacji wybranych teorii subiektywnych w kształceniu nauczycieli języków obcych. Wrocław: Wydawnictwo Uniwersytetu Wrocławskiego.

Montagne-Macaire, D. 2008. „D'une didactique des langues à une didactique des plurilinguismes? Réflexions pour la recherche". Les Cahiers de l'Acedle, vol. 5, $\mathrm{n}^{\circ} 1$ : 3-40.

Morisse, M. 2014. „Les dimensions réflexive et professionnalisante de l'écriture. Quelques considérations épistémologiques, théoriques et méthodologiques". (w:) L'écriture réflexive. Objet de recherche et de professionnalisation. (red. M. Morisse i L. Lafortune). Presses de l'Université du Québec, s. 10-29.

Polak, K. 1999. Indywidualne teorie nauczycieli. Geneza - badanie - kształtowanie. Kraków: Wydawnictwo Uniwersytetu Jagiellońskiego.

Robert, J.-P. i Rosen, É. 2010. Dictionnaire pratique du CECR. Paris: Éditions Ophrys. Sajdak, A. 2010. „Profesjonalizm dydaktyczny nauczycieli. Możliwości i ograniczenia akademickiego kształcenia". (w:) Etyka i profesjonalizm w zawodzie nauczyciela. (red. J. M. Michalak). Łódź: Wydawnictwo Uniwersytetu Łódzkiego, s. 123-142.

Samson, G. 2011. Le transfert a-t-il un avenir dans l'apprentissage et l'enseignement ?. Cahiers pédagogiques.com. http://www.cahiers-pedagogiq ues.com/Le-transfert-a-t-il-un-avenir-dans-I-apprentissage-et-I-enseig nement. DW 27.04.2016. 
Schön, D. A. 1983. The Reflective Practitioner. New York: New York Basic Books.

Smuk, M. 2016. Od cech osobowości do kompetencji savoir-être - rozwijanie samoświadomości w nauce języków obcych. Lublin-Warszawa: Werset/Instytut Romanistyki.

Sujecka-Zając, J. 2016.Kompetentny uczeń na lekcji języka obcego. Wyzwania dla glottodydaktyki mediacyjnej. Lublin-Warszawa: Werset/Instytut Romanistyki.

Szymankiewicz, K. 2013. „Między teorią a praktyką - przejawy teorii osobistych w refleksji przyszłych nauczycieli języka obcego podczas praktyk pedagogicznych". Neofilolog, 40/2: 265-277.

Szymankiewicz, K. 2017. Przyszli nauczyciele języków obcych na drodze budowania kompetencji zawodowej. Refleksja - uczenie się-rozwój. LublinWarszawa: Werset/Instytut Romanistyki.

Szymankiewicz, K. i Kucharczyk, R. 2016. „Mapy myśli jako narzędzie badania reprezentacji społecznych wielojęzyczności - przypadek przyszłych nauczycieli języka francuskiego". Neofilolog, 47/2: 187-203.

Szymankiewicz, K. 2018. (w druku) "Quelles compétences développer chez les futurs enseignants de français langue étrangère en Pologne pour profiter du profil plurilingue des apprenants polonophones ? "

Vacher, Y. 2015.Construire une pratique réflexive. Comprendre et agir. Louvain-la-Neuve: De Boeck Supérieur.

Zdybel, D. 2015. „Metapoznanie - ukryty wymiar kompetencji uczenia się”. (w:) Kompetencje kluczowe dzieci i młodzieży. Teoria i badania. (red. J. UszyńskaJarmoc i M. Bilewicz). Warszawa: Wydawnictwo Akademickie Żak, s. 54-70. 